Flores, J.N., Penchaszadeh, P.E., \& Brogger, M.I. (2021).

Heart urchins from the depths: Corparva lyrida gen. et sp. nov. (Palaeotropidae), and new records for the southwestern Atlantic Ocean. Revista de Biología Tropical, 69(S1), 14-34. DOI 10.15517/rbt. v69iSuppl.1.46320

DOI 10.15517/rbt.v69iSuppl.1.46320

\title{
Heart urchins from the depths: Corparva lyrida gen. et sp. nov. (Palaeotropidae), and new records for the southwestern Atlantic Ocean
}

\author{
Jonathan N. Flores ${ }^{1 *}$ \\ Pablo E. Penchaszadeh ${ }^{1}$ \\ Martín I. Brogger ${ }^{2}$
}

1. Laboratorio de Ecosistemas Costeros, Plataforma y Mar Profundo. Museo Argentino de Ciencias Naturales "Bernardino Rivadavia" (CONICET), Av. Ángel Gallardo 470, C1405DJR, Buenos Aires, Argentina; jflores@macn. gov.ar; pablopench@gmail.com

2. Laboratorio de Reproducción y Biología Integrativa de Invertebrados Marinos, Instituto de Biología de Organismos Marinos (CONICET), Bvd. Brown 2915, U9120ACD, Puerto Madryn, Chubut, Argentina; brogger@cenpat-conicet. gob.ar (*Correspondence).

Received 07-V-2020. Corrected 08-VIII-2020. Accepted 07-X-2020.

\begin{abstract}
Introduction: Sea urchins in the order Spatangoida are the most diverse group of extant echinoids. Objective: Describe a new genus and species of Spatangoida from abyssal depths, and add new records for known species. Methods: Specimens were collected during several cruises at different areas of the southwestern Atlantic

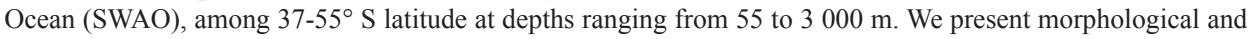
ultrastructure analyses. Results: Corparva lyrida gen. et sp. nov. (Palaeotropidae) is described from the Mar del Plata Canyon on the Argentine continental slope (2 $950 \mathrm{~m}$ depth), the first record of this family from Argentina. Corparva gen. nov. differs in having an apical system semi-ethmolytic, and labrum reaching to rear part of second adjacent ambulacral plate. We also report the northernmost distribution and deepest record for Brisaster moseleyi ( $38^{\circ} \mathrm{S}$ latitude, $2212 \mathrm{~m}$ depth), the northward extension of the distribution range of Tripylus excavatus (39 $\mathrm{S}$ latitude, $74 \mathrm{~m}$ depth), and the first record of Abatus philippii and Abatus agassizii at the Burdwood Bank/ MPA Namuncurá. Conclusions: The present work brings novel and updated data about the diversity and distribution of spatangoids from the SWAO, including the description of $C$. lyrida gen. et sp. nov., and new records of species. This shows how much remains to be known about the diversity and distribution of heart urchins in the SWAO, especially from the deep-sea.
\end{abstract}

Key words: Atelostomata; sea urchins; deep-sea; diversity; Argentina; MPA-N/BB.

Commonly known as heart urchins, the irregular echinoids of the order Spatangoida L. Agassiz, 1840 are represented in the fossil record since the lowermost Cretaceous (Berriasian, c. $145 \mathrm{Mya})$ and today are the most diverse group of extant echinoids (Villier, Néraudeau, Clavel, Neumann \& David, 2004; Stockley, Smith, Littlewood, Lessios \& Mackenzie-Dodds, 2005). Spatangoids are widely distributed throughout the ocean, from shallow waters to abyssal depths. Mostly spatangoids have evolved an infaunal lifestyle burrowing into the superficial layer of unconsolidated muddy and sandy sediments; however, some species living in the deep sea have adopted an epifaunal lifestyle (Mortensen, 1950; Mortensen,1951; Mironov, 1978). Owing to their ecological traits, heart urchins are 
considered important components of benthic communities. Spatangoids are deposit-feeders, they ingest a large amount of detritus from the sediment and cause bioturbation due to their locomotion and feeding mode (De Ridder, Jangoux \& De Vos, 1987; Lohrer, Thrush, Hunt, Hancock \& Lundquist, 2005). Concerning their reproductive aspects, spatangoids show broadcasting or brooding spawning modes, and indirect or direct developmental strategy, these life-history traits affects particularly the early larval dispersion and the distribution patterns of species (Poulin \& Féral, 1996, 1998).

The southwestern Atlantic Ocean (SWAO) receives waters formed in remotes areas of the world, generating one of the most energetic oceanic regions of the world (Piola \& Matano, 2001). Along the Argentine continental shelf, the upper ocean is mainly dominated by the Malvinas Current, a branch of the Antarctic Circumpolar Current that flows offshore to north, the Brazil Current, a branch of the subtropical gyre that flows south along the continental slope of South America, and by the Brazil/Malvinas Confluence, the collision of these two opposite currents near $38^{\circ} \mathrm{S}$ latitude (Matano, Palma \& Piola, 2010). Also, the deep layers from the continental slope off Argentina are characterized by a variety of water masses with origin in deep and bottom waters from the North Atlantic, South Pacific, and Antarctic regions (Piola \& Matano, 2001). According with several authors, two biogeographic provinces are recognized on the Argentine continental shelf by the patterns of distribution of different macroinvertebrates taxa: the Argentine Biogeographic Province (ABP), and the Magellan Biogeographic Province (MBP) (Bernasconi, 1964; Bastida, Roux \& Martínez, 1992; Doti, Roccatagliata \& López Gappa, 2014). The ABP extends from $23^{\circ} \mathrm{S}$ (Cabo Frio, Brazil) to $43^{\circ} \mathrm{S}$ (Península Valdés, Argentina), while the MBP is present on both sides of South America, from the southeastern Pacific Ocean at $41^{\circ} \mathrm{S}$ (Puerto Montt, Chile) reaching around the tip of South America into the SWAO at $43^{\circ} \mathrm{S}$ latitude, where the MBP turns aside from shallow shelf waters following a northeastern direction to more deep shelf waters, as far as $35^{\circ} \mathrm{S}$ latitude (López Gappa, Alonso \& Landoni, 2006; Doti et al., 2014).

Based on previous reports, there are eight spatangoids species present in the Argentine continental shelf and offshore: Abatus cavernosus (Philippi, 1845); Abatus philippii Lovén, 1871; Abatus agassizii Mortensen, 1910; Brisaster moseleyi (A. Agassiz, 1881); Tripylaster philippii (Gray, 1851); Tripylus excavatus (Philippi, 1845); Tripylus reductus (Koehler, 1912); and Delopatagus brucei Koehler, 1907 (Bernasconi, 1964; Brogger et al., 2013; FabriRuiz, Saucède, Danis \& David, 2017; Saucède et al., 2020). D. brucei is considered due to its occurrence south off Tierra del Fuego (Saucède et al., 2020).

This paper aims to contribute to improving the knowledge of the diversity and distribution of the Spatangoida from the SWAO, through the study of specimens recently collected. Here we describe a new genus and species of Palaeotropidae from the Mar del Plata Canyon, which represents the first report for this family in Argentina. Besides, we inform new records in the SWAO for other known species.

\section{MATERIALS AND METHODS}

The study area is located at the southern extreme of the SWAO, from $37^{\circ}$ to $55^{\circ} \mathrm{S}$ latitude at depths encompassing from the shallow waters of the continental shelf to abyssal waters of the slope off the Argentine coast (Fig. 1A).

The specimens were collected from several sites during eight cruises at different areas within the SWAO: continental shelf and slope off Buenos Aires, the Mar del Plata Canyon, San Jorge Gulf, Patagonian shelf, and the Marine Protected Area Namuncurá/Banco Burdwood (MPA-N/BB). These cruises were: "Mejillón II" (M II), 2009, 9-150 m depth, 3 sites; "Talud Continental I" (TC I), 2012, 200-3 006 m depth, 6 sites; "Talud Continental II" (TC II), 2013, 78-1 289 m depth, 2 sites; "Talud Continental III" (TC III), 2013, 1 310-3 447 m depth, 5 sites; "Área Marina Protegida Namuncurá/Banco Burdwood: Bentos” 

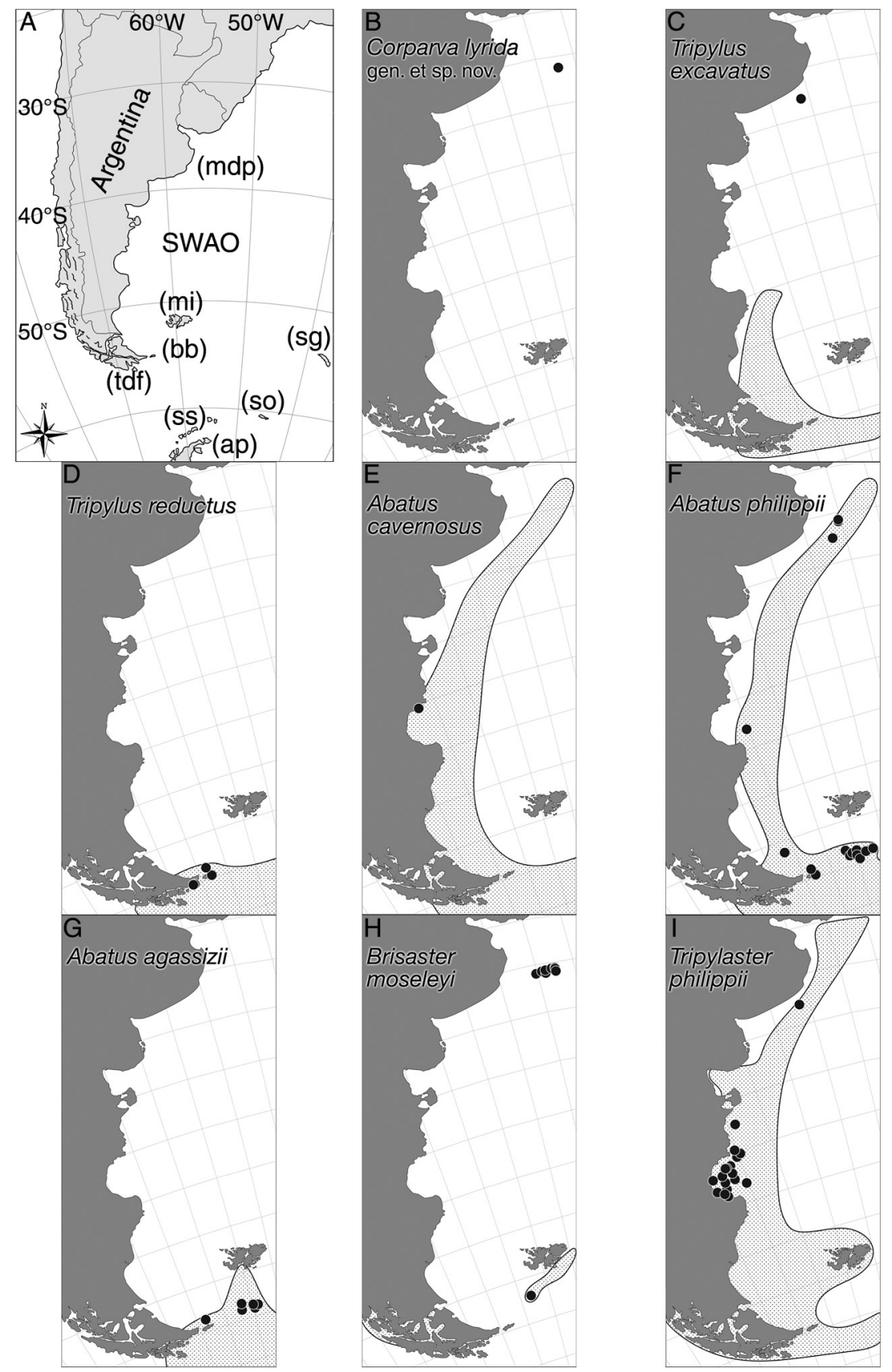

Fig. 1. Maps showing the studied area with the distribution of the species discussed in the present study. A. Positions for the main locations from the southwestern Atlantic Ocean discussed in this study. B. Corparva lyrida gen. et sp. nov. C. Tripylus excavatus. D. Tripylus reductus. E. Abatus cavernosus. F. Abatus philippii. G. Abatus agassizii. H. Brisaster moseleyi. I. Tripylaster philippii. B-I. species herein examined (marked signs) plotted on their previously registered distribution (dotted area). References: A. SWAO, southwestern Atlantic Ocean; $m d p$, Mar del Plata Canyon; $m i$, Malvinas Islands; $b b$, Marine Protected Area Namuncurá/Banco Burdwood; $t d f$, Tierra del Fuego; $s g$, South Georgia Islands; so, South Orkney Islands; ss, South Shetland Islands; and ap, Antarctic Peninsula. 
(AMP-N/BB-2016), 2016, 71-785 m depth, 16 sites; "PD BB ABR 17" (AMP-N/BB-2017), 2017, 48-646 m depth, 9 sites, "Pampa Azul Golfo San Jorge-BO/PD-GSJ-02-2017" (GSJ 2017), 2017, 36-106 m depth, 19 sites, and "AMP Namuncurá/Banco Burdwood: Ingenieros Ecosistémicos” (AMP-N/BB-2018), 2018, 78-694 m depth, 2 sites (Table 1). All cruises were performed on board of the R/V Puerto Deseado from CONICET.
Specimens were collected using an adapted towed dredge or a bottom trawl net. The towed dredge used consisted of a rigid body structure $150 \mathrm{~cm}$ long and $100 \mathrm{~cm}$ wide, with a $60 \mathrm{~cm}$ wide by $40 \mathrm{~cm}$ high mouth frame and carrying two joint fishing nets with two different pore-size (an external one of $3 \times 3 \mathrm{~cm}$, with another internal one of $1 \times 1 \mathrm{~cm}$ ).

Once onboard, specimens were fixed in 96 $\%$ ethanol. All the specimens are now housed

TABLE 1

Collection data of the specimens studied

\begin{tabular}{|c|c|c|c|c|c|c|c|}
\hline MACN-In & Expedition - Station - Site & Lat. (S) & Long. (W) & Depth (m) & Date (yy-mm-dd) & Spms. & Fishing gear \\
\hline 43269 & M II - 7 & $38^{\circ} 46^{\prime} 34^{\prime \prime}$ & $55^{\circ} 50^{\prime} 38^{\prime \prime}$ & 92 & 2009-09-11 & 1 & towed dredge \\
\hline 43270 & M II - 10 & $39^{\circ} 05^{\prime} 49^{\prime \prime}$ & $58^{\circ} 02^{\prime} 09^{\prime \prime}$ & 74 & 2009-09-12 & 3 & towed dredge \\
\hline 43271 & M II - 11 & $39^{\circ} 01 ' 23^{\prime \prime}$ & $58^{\circ} 10^{\prime} 02^{\prime \prime}$ & 55 & 2009-09-12 & 3 & towed dredge \\
\hline 43272 & TC I - 2 & $37^{\circ} 57^{\prime} 11^{\prime \prime}$ & $55^{\circ} 11^{\prime} 03^{\prime \prime}$ & 291 & 2012-08-10 & 1 & towed dredge \\
\hline 43273 & TC I - 3 & $37^{\circ} 59^{\prime} 39^{\prime \prime}$ & $55^{\circ} 13^{\prime} 03^{\prime \prime}$ & 250 & 2012-08-10 & 16 & bottom trawl net \\
\hline 43274 & TC I - 5 & $37^{\circ} 58^{\prime} 39^{\prime \prime}$ & $55^{\circ} 09^{\prime} 06^{\prime \prime}$ & 528 & 2012-08-10 & 1 & bottom traw1 net \\
\hline 43275 & TC I - 14 & $38^{\circ} 00^{\prime} 59^{\prime \prime}$ & $54^{\circ} 30^{\prime} 19^{\prime \prime}$ & 1006 & 2012-08-11 & 2 & bottom trawl net \\
\hline 43276 & TC I - 32 & $37^{\circ} 59^{\prime} 48^{\prime \prime}$ & $55^{\circ} 12^{\prime} 29^{\prime \prime}$ & 319 & $2012-08-17$ & 1 & towed dredge \\
\hline 43277 & TC I - 33 & $37^{\circ} 58^{\prime} 42^{\prime \prime}$ & $55^{\circ} 11^{\prime} 54^{\prime \prime}$ & 308 & $2012-08-17$ & 2 & bottom trawl net \\
\hline 43278 & TC II - 43 & $37^{\circ} 53^{\prime} 50^{\prime \prime}$ & $54^{\circ} 30^{\prime} 27^{\prime \prime}$ & 998 & $2013-05-26$ & 1 & bottom traw1 net \\
\hline 43279 & TC II - 44 & $37^{\circ} 53^{\prime} 33^{\prime \prime}$ & $54^{\circ} 42^{\prime} 56^{\prime \prime}$ & 780 & $2013-05-26$ & 3 & bottom trawl net \\
\hline 43280 & TC III - 47 & $38^{\circ} 06^{\prime} 34^{\prime \prime}$ & $53^{\circ} 42^{\prime} 50^{\prime \prime}$ & 2950 & 2013-09-06 & 1 & bottom trawl net \\
\hline 43281 & TC III - 51 & $38^{\circ} 01^{\prime} 23^{\prime \prime}$ & $53^{\circ} 51^{\prime} 00^{\prime \prime}$ & 2212 & 2013-09-07 & 1 & bottom traw 1 net \\
\hline 43282 & TC III - 53 & $37^{\circ} 52^{\prime} 37^{\prime \prime}$ & $53^{\circ} 54^{\prime} 15^{\prime \prime}$ & 1763 & 2013-09-08 & 12 & bottom trawl net \\
\hline 43283 & TC III - 55 & $37^{\circ} 52^{\prime} 09^{\prime \prime}$ & $53^{\circ} 51^{\prime} 35^{\prime \prime}$ & 1712 & 2013-09-08 & 9 & bottom trawl net \\
\hline 43284 & TC III - 59 & $37^{\circ} 49^{\prime} 41^{\prime \prime}$ & $54^{\circ} 5^{\prime} 14^{\prime \prime}$ & 1398 & 2013-09-10 & 1 & bottom trawl net \\
\hline 43285 & AMP-N/BB-2016 - 5 - 126 & $55^{\circ} 02^{\prime} 17^{\prime \prime}$ & $65^{\circ} 46^{\prime} 07^{\prime \prime}$ & 118 & 2016-04-06 & 1 & towed dredge \\
\hline 43286 & AMP-N/BB-2016 - 5 - 127 & $55^{\circ} 02^{\prime} 15^{\prime \prime}$ & $65^{\circ} 48^{\prime} 24^{\prime \prime}$ & 114 & 2016-04-06 & 1 & bottom traw1 net \\
\hline 43287 & AMP-N/BB-2016 - 11 - 338 & $54^{\circ} 30^{\prime} 06^{\prime \prime}$ & $64^{\circ} 12^{\prime} 06^{\prime \prime}$ & 107 & 2016-04-22 & 1 & bottom trawl net \\
\hline 43288 & AMP-N/BB-2016 - 23 - 226 & $54^{\circ} 45^{\prime} 34^{\prime \prime}$ & $59^{\circ} 52^{\prime} 08^{\prime \prime}$ & 182 & 2016-04-13 & 1 & bottom trawl net \\
\hline 43289 & AMP-N/BB-2016 - 26 - 24 & $54^{\circ} 24^{\prime} 13^{\prime \prime}$ & $58^{\circ} 28^{\prime} 17^{\prime \prime}$ & 135 & 2016-03-29 & 1 & towed dredge \\
\hline 43290 & AMP-N/BB-2016 - 26 - 27 & $54^{\circ} 24^{\prime} 57^{\prime \prime}$ & $58^{\circ} 30^{\prime} 55^{\prime \prime}$ & 137 & 2016-03-29 & 1 & bottom trawl net \\
\hline 43291 & AMP-N/BB-2016 - 28 - 50 & $54^{\circ} 28^{\prime} 50^{\prime \prime}$ & $59^{\circ} 11^{\prime} 40^{\prime \prime}$ & 122 & 2016-03-30 & 1 & towed dredge \\
\hline 43292 & AMP-N/BB-2016 - 30 - 185 & $54^{\circ} 16^{\prime} 40^{\prime \prime}$ & $59^{\circ} 57^{\prime} 47^{\prime \prime}$ & 96 & 2016-04-10 & 1 & towed dredge \\
\hline 43293 & AMP-N/BB-2016 - 31 - 197 & $54^{\circ} 29^{\prime} 58^{\prime \prime}$ & $59^{\circ} 51^{\prime} 32^{\prime \prime}$ & 109 & 2016-04-10 & 3 & bottom trawl net \\
\hline 43294 & AMP-N/BB-2016 - 32 - 77 & $54^{\circ} 32^{\prime} 36^{\prime \prime}$ & $60^{\circ} 01^{\prime} 17^{\prime \prime}$ & 98 & 2016-03-30 & 1 & bottom traw1 net \\
\hline 43295 & AMP-N/BB-2016 - 33 - 159 & $54^{\circ} 25^{\prime} 46^{\prime \prime}$ & $60^{\circ} 38^{\prime} 52^{\prime \prime}$ & 101 & 2016-04-08 & 5 & bottom trawl net \\
\hline 43296 & AMP-N/BB-2016 - 34 - 156 & $54^{\circ} 27^{\prime} 15^{\prime \prime}$ & $60^{\circ} 58^{\prime} 49^{\prime \prime}$ & 100 & 2016-04-07 & 15 & bottom trawl net \\
\hline 43297 & AMP-N/BB-2016 - 39 - 141 & $54^{\circ} 50^{\prime} 41^{\prime \prime}$ & $63^{\circ} 59^{\prime} 54^{\prime \prime}$ & 183 & 2016-04-06 & 1 & bottom traw1 net \\
\hline 43298 & AMP-N/BB-2016 - 39 - 141 & $54^{\circ} 50^{\prime} 41^{\prime \prime}$ & $63^{\circ} 59^{\prime} 54^{\prime \prime}$ & 183 & 2016-04-06 & 2 & bottom trawl net \\
\hline 43299 & AMP-N/BB-2016 - 41 - 350 & $54^{\circ} 19^{\prime} 55^{\prime \prime}$ & $64^{\circ} 14^{\prime} 15^{\prime \prime}$ & 122 & 2016-04-22 & 1 & bottom trawl net \\
\hline 43300 & AMP-N/BB-2016 - 41 - 350 & $54^{\circ} 19^{\prime} 55^{\prime \prime}$ & $64^{\circ} 14^{\prime} 15^{\prime \prime}$ & 122 & 2016-04-22 & 5 & bottom trawl net \\
\hline 43301 & AMP-N/BB-2017 - 5- 10 & $53^{\circ} 07^{\prime} 41^{\prime \prime}$ & $65^{\circ} 47^{\prime} 08^{\prime \prime}$ & 294 & $2017-04-23$ & 2 & towed dredge \\
\hline 43302 & AMP-N/BB-2017 - 9 - 49 & $54^{\circ} 52^{\prime} 34^{\prime \prime}$ & $64^{\circ} 17^{\prime} 46^{\prime \prime}$ & 146 & $2017-04-24$ & 1 & towed dredge \\
\hline
\end{tabular}


TABLE 1 (Continued)

\begin{tabular}{|c|c|c|c|c|c|c|c|}
\hline MACN-In & Expedition - Station - Site & Lat. (S) & Long. (W) & Depth (m) & Date (yy-mm-dd) & Spms. & Fishing gear \\
\hline 43303 & AMP-N/BB-2017 - 23 - 173 & $54^{\circ} 26^{\prime} 06^{\prime \prime}$ & $59^{\circ} 30^{\prime} 15^{\prime \prime}$ & 91 & $2017-05-01$ & 1 & bottom trawl net \\
\hline 43304 & AMP-N/BB-2017 - 24 - 184 & $54^{\circ} 19^{\prime} 57^{\prime \prime}$ & $59^{\circ} 53^{\prime} 45^{\prime \prime}$ & 97 & 2017-05-01 & 1 & bottom traw 1 net \\
\hline 43305 & AMP-N/BB-2017 - 25 - 304 & $54^{\circ} 20^{\prime} 46^{\prime \prime}$ & $60^{\circ} 20^{\prime} 46^{\prime \prime}$ & 104 & 2017-05-09 & 1 & bottom trawl net \\
\hline 43306 & AMP-N/BB-2017 - 27 - 326 & $54^{\circ} 06^{\prime} 27^{\prime \prime}$ & $60^{\circ} 52^{\prime} 46^{\prime \prime}$ & 128 & 2017-05-09 & 1 & bottom trawl net \\
\hline 43307 & AMP-N/BB-2017 - 27 - 326 & $54^{\circ} 06^{\prime} 27^{\prime \prime}$ & $60^{\circ} 52^{\prime} 46^{\prime \prime}$ & 128 & 2017-05-09 & 1 & bottom trawl net \\
\hline 43308 & AMP-N/BB-2017 - 27 - 327 & $54^{\circ} 06^{\prime} 27^{\prime \prime}$ & $60^{\circ} 52^{\prime} 46^{\prime \prime}$ & 132 & 2017-05-09 & 2 & towed dredge \\
\hline 43309 & AMP-N/BB-2017 - 31 - 269 & $53^{\circ} 40^{\prime} 21^{\prime \prime}$ & $61^{\circ} 38^{\prime} 15^{\prime \prime}$ & 642 & 2017-05-07 & 38 & bottom traw1 net \\
\hline 43310 & GSJ 2017 - 3 - ID 55 & $43^{\circ} 43^{\prime} 12^{\prime \prime}$ & $64^{\circ} 31^{\prime} 48^{\prime \prime}$ & 65 & $2017-10-29$ & 1 & bottom trawl net \\
\hline 43311 & GSJ 2017 - 11 - ID 42 & $44^{\circ} 53^{\prime} 24^{\prime \prime}$ & $65^{\circ} 08^{\prime} 24^{\prime \prime}$ & 84 & $2017-10-31$ & 4 & bottom trawl net \\
\hline 43312 & GSJ 2017 -12 - ID 41 & $45^{\circ} 08^{\prime} 24^{\prime \prime}$ & $64^{\circ} 50^{\prime} 60^{\prime \prime}$ & 83 & $2017-10-31$ & 1 & bottom traw1 net \\
\hline 43313 & GSJ 2017 - 13 - ID 39 & $45^{\circ} 14^{\prime} 24^{\prime \prime}$ & $65^{\circ} 09^{\prime} 00^{\prime \prime}$ & 91 & $2017-10-31$ & 1 & bottom trawl net \\
\hline 43314 & GSJ 2017 - 17 - ID 36 & $45^{\circ} 13^{\prime} 12^{\prime \prime}$ & $66^{\circ} 13^{\prime} 48^{\prime \prime}$ & 78 & 2017-11-01 & 1 & bottom trawl net \\
\hline 43315 & GSJ 2017 - 23 - ID 32 & $45^{\circ} 34^{\prime} 48^{\prime \prime}$ & $66^{\circ} 11^{\prime} 24^{\prime \prime}$ & 94 & $2017-11-02$ & 38 & bottom trawl net \\
\hline 43316 & GSJ 2017 - 24 - ID 31 & $45^{\circ} 32^{\prime} 24^{\prime \prime}$ & $65^{\circ} 48 \cdot 36^{\prime \prime}$ & 98 & $2017-11-02$ & 2 & bottom trawl net \\
\hline 43317 & GSJ 2017 - 26 - ID 29 & $45^{\circ} 34^{\prime} 48^{\prime \prime}$ & $66^{\circ} 07^{\prime} 48^{\prime \prime}$ & 83 & $2017-11-02$ & 1 & bottom traw1 net \\
\hline 43318 & GSJ 2017 - 29 - ID 26 & $45^{\circ} 55^{\prime} 12^{\prime \prime}$ & $65^{\circ} 50^{\prime} 24^{\prime \prime}$ & 99 & $2017-11-03$ & 1 & bottom trawl net \\
\hline 43319 & GSJ 2017 - 31 - ID 24 & $45^{\circ} 53^{\prime} 60^{\prime \prime}$ & $66^{\circ} 35^{\prime} 24^{\prime \prime}$ & 96 & $2017-11-03$ & 47 & bottom traw1 net \\
\hline 43320 & GSJ 2017 - 33 - ID 22 & $45^{\circ} 54^{\prime} 36^{\prime \prime}$ & $67^{\circ} 18^{\prime} 36^{\prime \prime}$ & 72 & $2017-11-03$ & 1 & bottom trawl net \\
\hline 43321 & GSJ 2017 - 37 - ID 19 & $46^{\circ} 13^{\prime} 48^{\prime \prime}$ & $66^{\circ} 33^{\prime} 36^{\prime \prime}$ & 99 & 2017-11-04 & 4 & bottom trawl net \\
\hline 43322 & GSJ 2017 - 39 - ID 17 & $46^{\circ} 14^{\prime} 24^{\prime \prime}$ & $65^{\circ} 49^{\prime} 12^{\prime \prime}$ & 98 & 2017-11-04 & 26 & bottom trawl net \\
\hline 43323 & GSJ 2017 - 42 - ID 14 & $46^{\circ} 34^{\prime} 48^{\prime \prime}$ & $65^{\circ} 08^{\prime} 24^{\prime \prime}$ & 106 & $2017-11-05$ & 1 & bottom trawl net \\
\hline 43324 & GSJ 2017 - 42 - ID 14 & $46^{\circ} 34^{\prime} 48^{\prime \prime}$ & $65^{\circ} 08^{\prime} 24^{\prime \prime}$ & 106 & $2017-11-05$ & 1 & bottom traw1 net \\
\hline 43325 & GSJ 2017 - 54 - ID 68 & $46^{\circ} 54^{\prime} 36^{\prime \prime}$ & $66^{\circ} 42^{\prime} 36^{\prime \prime}$ & 57 & 2017-11-06 & 1 & bottom trawl net \\
\hline 43326 & GSJ 2017 - 55 - ID 69 & $46^{\circ} 45^{\prime} 36^{\prime \prime}$ & 665'36" & 74 & $2017-11-07$ & 1 & bottom trawl net \\
\hline 43327 & GSJ 2017 - 56 - ID 8 & $46^{\circ} 32^{\prime} 24^{\prime \prime}$ & $67^{\circ} 19^{\prime} 48^{\prime \prime}$ & 74 & 2017-11-07 & 5 & bottom traw 1 net \\
\hline 43328 & GSJ 2017 - 59 - ID 10 & $46^{\circ} 33^{\prime} 36^{\prime \prime}$ & 663'ㅇ' & 95 & 2017-11-07 & 11 & bottom trawl net \\
\hline 43329 & AMP-N/BB-2018 - 1 - 157 & $54^{\circ} 53^{\prime} 00^{\prime \prime}$ & $67^{\circ} 48^{\prime} 36^{\prime \prime}$ & 140 & 2018-09-01 & 3 & bottom trawl net \\
\hline 43330 & AMP-N/BB-2018 - 25- 120 & $54^{\circ} 30^{\prime} 48^{\prime \prime}$ & $60^{\circ} 25^{\prime} 35^{\prime \prime}$ & 100 & $2018-08-28$ & 1 & bottom trawl net \\
\hline
\end{tabular}

References: $M$ II "Mejillon II" expedition; TC I "Talud Continental I" expedition; TC II "Talud Continental II" expedition; TC III "Talud Continental III" expedition; $A M P-N / B B-2016$ "Area Marina Protegida Namuncurá - Banco Burdwood" expedition; $A M P-N / B B-2017$ "PD BB ABR 17" expedition; $A M P-N / B B-2018$ "AMP Namuncurá/Banco Burdwood: Ingenieros Ecosistémicos" expedition; GSJ 2017 "Pampa Azul Golfo San Jorge-BO/PD-GSJ-02-2017" expedition; and Spms. number of specimens.

in the National Invertebrate Collection of the Museo Argentino de Ciencias Naturales "Bernardino Rivadavia" (MACN-In) from Buenos Aires, Argentina.

Gross morphology of specimens was studied under naked eye and using a stereomicroscope, while the ultrastructure of several appendages was analyzed by scanning electron microscopy (SEM). Test measures were made with a digital caliper. To be able to reveal the arrangement of the plates, some specimens were carefully cleaned. Appendages and soft tissue were removed from the test with tweezers, and a small brush soaked with a diluted solution of sodium hypochlorite was used to remove the organic remains. When the plates and sutures were exposed and visible, the whole specimen was rinsed in distilled water. Plates were labelled according to the standard nomenclature for the test plating provided by Lovén (1874).

For SEM images, appendages (spines, pedicellariae, sphaeridia, and tube feet) were removed from different parts of the test and placed into distilled water. Organic remains were cleared with a diluted solution of sodium 
hypochlorite for a few minutes. The appendages were rinsed in distilled water twice, followed by a third rinse with $96 \%$ ethanol to allow rapid air drying. Finally, appendages were transferred to aluminium stubs, sputtered with gold-palladium, and examined and photographed with a Philips XL30 scanning microscope at the Museo Argentino de Ciencias Naturales "Bernardino Rivadavia" (MACN). Complete specimens were photographed using a Nikon D800 camera with a Micro-Nikkor 60 $\mathrm{mm} \mathrm{f} / 2.8$ lens, and details of the plates from the test were photographed with a Zeiss Discovery V20 stereoscopic microscope.

This article is registered in ZooBank under ID: urn:1sid:zoobank.org:pub:2FBDDA8FDB8A-4266-B606-553AF5C2F366.

\section{RESULTS}

In all, 299 specimens of spatangoids were collected and studied, identifying eight species distributed in two families, and six genera. In the present study, we report a new genus and species Corparva lyrida (Spatangoida: Palaetropidae) along with the occurrence and new records in the SWAO of known species.

In the Taxonomic List are listed the species identified following the classification of Kroh (2020) for higher-level taxa, Saucède et al. (2020) for the family Schizasteridae and its lower-level taxa, and Kroh \& Mooi (2020) for the Palaeotropidae family.

\section{Taxonomic List:}

Phylum Echinodermata Bruguière, 1791

Class Echinoidea Leske, 1778

Order Spatangoida L. Agassiz, 1840

Suborder Paleopneustina Markov \& Solovjev, 2001

Family Schizasteridae Lambert, 1905

Genus Tripylus Philippi, 1845

Tripylus excavatus (Philippi, 1845)

Tripylus reductus (Koehler, 1912)

Genus Abatus Troschel, 1851

Abatus cavernosus (Philippi, 1845)

Abatus philippii Lovén, 1871

Abatus agassizii Mortensen, 1910
Genus Brisaster Gray, 1855

Brisaster moseleyi (A. Agassiz, 1881)

Genus Tripylaster Mortensen, 1907

Tripylaster philippii (Gray, 1851)

Suborder Brissidina Kroh \& Smith, 2010 (= Brissidea of Stockley et al., 2005)

Family Palaeotropidae Lambert, 1896

Genus Corparva Flores, Penchaszadeh \& Brogger gen. nov.

Corparva lyrida Flores, Penchaszadeh \& Brogger sp. nov.

\section{Systematics:}

Order Spatangoida L. Agassiz, 1840

Suborder Brissidina Kroh \& Smith, 2010

Family Palaeotropidae Lambert, 1896

Corparva Flores, Penchaszadeh \& Brogger gen. nov.

Diagnosis: Test ovoid, small size, truncated posterior end. Semi-ethmolytic apical system, four gonopores. No frontal notch. Paired ambulacra apetaloid, pore-pairs small and rudimentary. Fascioles absent. Periproct on the posterior end, slightly inframarginal. Peristome D-shaped, sunken. Labrum narrow, not projecting over the peristome, reaching to rear part of second adjacent ambulacral plate. Plastron amphisternous, domed in profile. Primary spines slender, more abundant on aboral side, lacking on posterior ambulacral areas on oral side. Pedicellariae present: tridentate, globiferous, and triphyllous.

Type species: Corparva lyrida Flores, Penchaszadeh \& Brogger sp. nov.

Etymology: Cor alluding for heart and parva for small (gender feminine).

ZooBank ID: urn:lsid:zoobank. org:act:13ACEDA6-DA67-414A-BBEE9FB20288223F

Remarks: Corparva gen. nov. is included into the family Palaeotropidae Lambert, 1896 based on structural features as a thin ovate test, no frontal notch, paired ambulacra apetaloid, reduced peristome D-shaped, sternal plates symmetrical and fully tuberculate, episternal plates paired, and aboral surface with scattered small tubercles (Smith \& Gale, 2009; Smith 
\& Kroh, 2011). However, Corparva gen. nov. can be clearly separated from other genera of Palaeotropidae by possessing an apical system semi-ethmolytic, labral plate reaching to rear part of second adjacent ambulacral plate, and paired ambulacra deeply depressed forming rounded pouches (at least in females). We considered these features serve to distinguish our new species $C$. lyrida supporting the erection of a new genus.

As Néraudeau, David \& Madon (1998) pointed out, the arrangement of the plates in the apical system should not be used as a morphological character to differentiate at family level, due to changes in the structure of the apical system occurred convergently in many different groups of spatangoids. Thus, we consider the semi-ethmolytic pattern of Corparva gen. nov. and the labral plate extending to the rear part of second adjacent ambulacral plate as features to separates it from the other genera of Palaeotropidae.

Palaeotropus Lovén, 1874 differs by possessing an apical system monobasal with fused genital plates, anterior, two gonopores, paired ambulacra flush, uniserial ambulacral plates adapically, labral plate extending to rear of the first adjacent ambulacral plate, episternal plates strongly tapered to posterior, strong subanal heel, rounded subanal fasciole, row of larger tubercles and spines bordering the frontal ambulacrum, and ophicephalus pedicellariae present (Lóven, 1871; Lóven, 1874; Mortensen, 1950; Mironov, 2006; Kroh \& Mooi, 2020).

Palaeobrissus A. Agassiz, 1883 differs by its ethmolytic apical system with fused genital plates, anterior, two gonopores in the posterior genital plates surrounded by a rim and sometimes two smaller anterior gonopores in large specimens, paired ambulacra flush, subpetaloid with ambulacral pores double, peristome not sunken and transversally oval, labral plate extending to first adjacent ambulacral plate, slightly projecting over peristome, and rounded subanal fasciole present in juveniles (lost in adults) (Agassiz, 1883; Mortensen; 1950; Kroh \& Mooi, 2020).
Paleotrema Koehler, 1914 differs by having a test elongated, posterior end obliquely truncated, monobasal apical system with fused genital plates, anterior, three gonopores, paired ambulacra flush, labral plate extending to first adjacent ambulacral plate, episternal plates strongly tapered to posterior, plastron forming keel posteriorly, rounded subanal fasciole, row of larger tubercles and spines bordering the frontal ambulacrum, ophicephalus pedicellariae present and globiferous absent (Agassiz, 1879; Koehler, 1914; Mortensen, 1950; Kroh \& Mooi, 2020).

Scrippsechinus Allison, Durham \& Mintz, 1967 differs by possessing ethmolytic apical system with fused genital plates, subcentral, paired ambulacra flush, uniserial ambulacral plates adapically, labral plate not extending beyond first adjacent ambulacral plate, projecting over peristome, and globiferous pedicellariae absent (Allison, Durham \& Mintz, 1967; Kroh \& Mooi, 2020).

Kermabrissoides Baker, 1998 differs by its ethmolytic apical system, subcentral, gonopores on top of small cones, paired ambulacra flush, subpetaloid, labral plate extending to third adjacent ambulacral plate, rounded subanal fasciole with 2-3 tube feet either side, ophicephalus pedicellariae present and globiferous absent (Baker \& Rowe, 1990; Baker, 1998; Kroh \& Mooi, 2020).

\section{Corparva lyrida}

Flores, Penchaszadeh \& Brogger sp. nov.

Diagnosis: As for the genus.

Description: Test fragile, low in profile, oval in outline with truncated posterior end, anterior part wider than posterior part, rounded at ambital edge, wedge-shaped in lateral profile (Fig. 2A, Fig. 2B, Fig. 2C, Fig. 2D, Fig. 2E, Fig. 3A, Fig. 3B, Fig. 3C, Fig. 3D, Fig. 3E). Small test size, $18.2 \mathrm{~mm}$ long, $14.8 \mathrm{~mm}$ wide, and $6.0 \mathrm{~mm}$ high. Fascioles absent (Fig. 2A, Fig. 2B, Fig. 2C, Fig. 2D, Fig. 2E, Fig. 3A, Fig. 3B, Fig. 3C, Fig. 3D, Fig. 3E). Apical system central, sunken with respect to adjacent interambulacral areas, semi-ethmolytic, with 


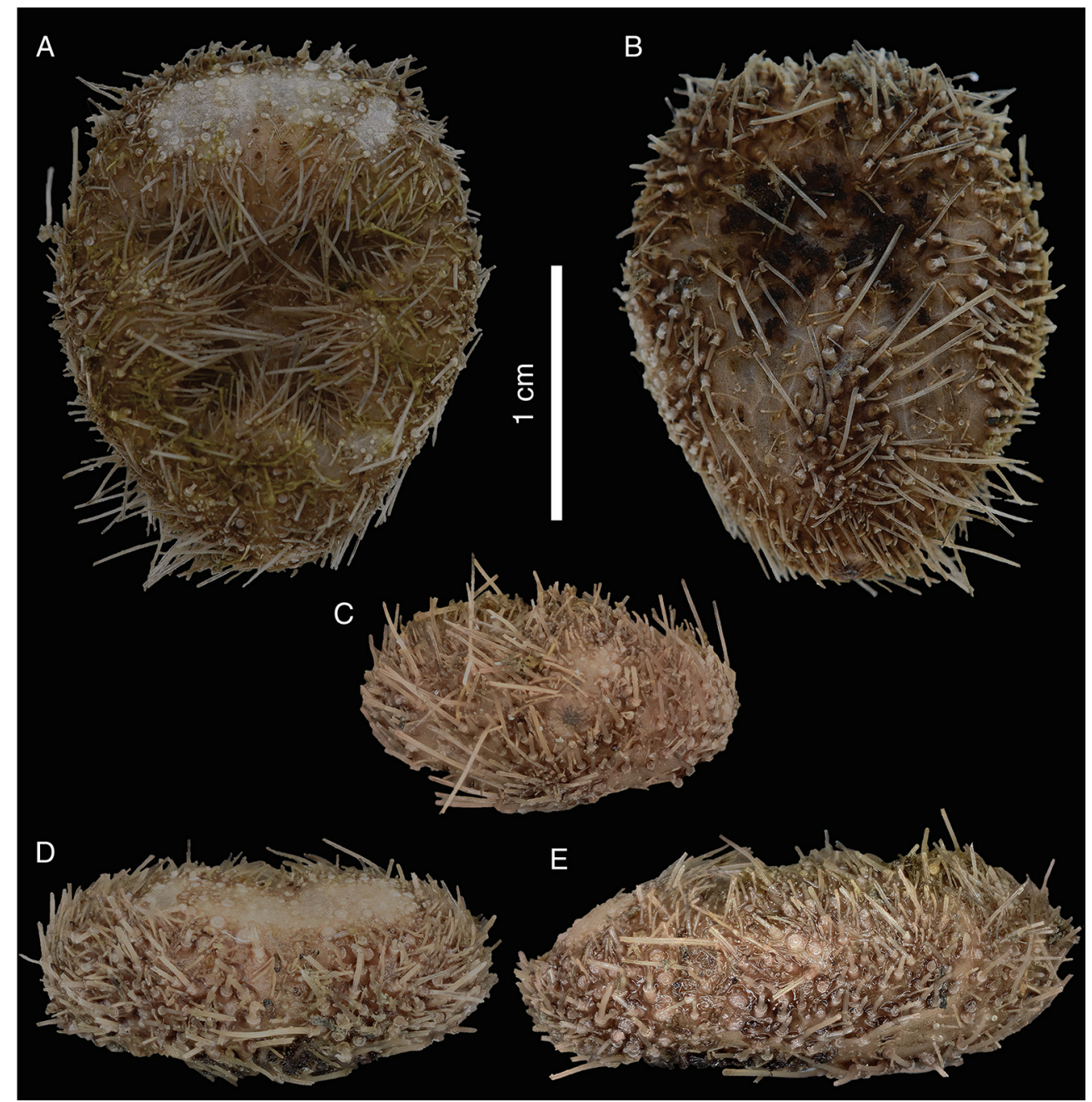

Fig. 2. Corparva lyrida gen. et sp. nov. (Holotype MACN-In 43280), complete specimen. A. Aboral view. B. Oral view. C. Posterior view. D. Anterior view. E. Side view (anterior to the left).

four genital pores of same size opening on inner part of genitals (Fig. 2A, Fig. 3A, Fig. 4A, Fig. 4D). Madreporic plate (G2) enlarged posteriorly between genitals 1 and 4 but not separating oculars V from I, hydropores scarce (Fig. 4D). Frontal notch absent, ambulacrum III flush with test (Fig. 2A, Fig. 2D, Fig. 3A, Fig. 3D). Non-petaloid paired ambulacra, cruciform, deeply depressed forming rounded pouches (Fig 3A), double row of ambulacral plates adapically. Ambulacral tube feet simple on aboral side, pore-pairs small and rudimentary, there are no occluded plates at the end of the paired ambulacra, posterior paired ambulacra slightly shorter than anterior. Paired ambulacra pouches reaching fifth ambulacral plate (from apex to ambitus) in ambulacrum IV and $\mathrm{V}$, tuberculation on these plates scarce. Plates from ambulacra II and IV remain parallel-sided on oral side (Fig 3B). Peristome D-shaped, sunken, situated between $25-34 \%$ of test length from anterior edge, upper peristome portion occupied by many plates of different sizes, becoming smaller surrounding mouth (Fig. 3B, Fig. 4C, Fig. 4F). Phyllodes reaching fourth plate in paired ambulacra. Penicillate tube feet 


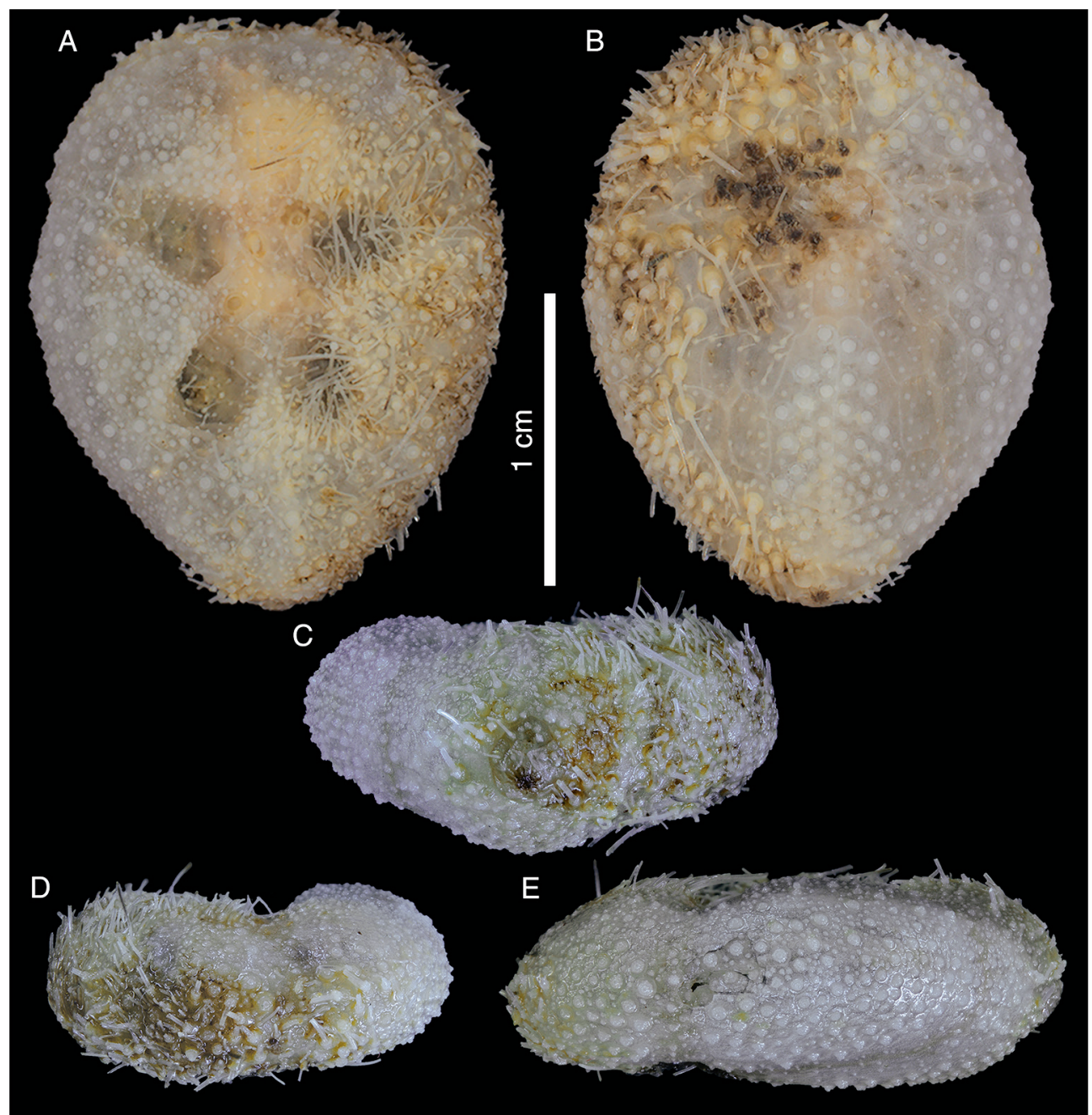

Fig. 3. Corparva lyrida gen. et sp. nov. (Holotype MACN-In 43280), specimen partially cleaned. A. Aboral view. B. Oral view. C. Posterior view. D. Anterior view. E. Side view (anterior to the left).

conspicuous (Fig. 2B, Fig. 3B), terminating in well-developed disc with finger-like projections, each supported by a skeletal rod (Fig. $5 \mathrm{G})$. Interambulacrum 5 continuous, posterior part forming slightly keel (Fig. 2E, Fig. 3E). Labral plate not projecting over peristome, narrow, in contact with both sternal plates, extending to rear part of second adjacent ambulacral plate (Fig. 4C, Fig. 4F). Plastron amphisternous (Fig. 4F). Sternal plates symmetrical, slightly bowed, extending to fifth adjacent ambulacral plate, posterior suture of plate 5.b.2 coincides with fifth plate in ambulacrum I (Fig. 4F). Episternal plates paired and opposite. Basicoronal plate amphiplacous in interambulacrum 4. Periproct circular, located on posterior vertical end, inframarginal, visible from oral side, covered by plates of variable sizes and shapes, larger plates close to external edge and smaller plates towards center (Fig. 2B, Fig. 2C, Fig. 3B, Fig. 3C). Distinct subanal tube feet absent. Primary tubercles numerous and uniformly spaced on aboral surface and absent on ambulacral areas on oral side up to fifth plate in ambulacrum 

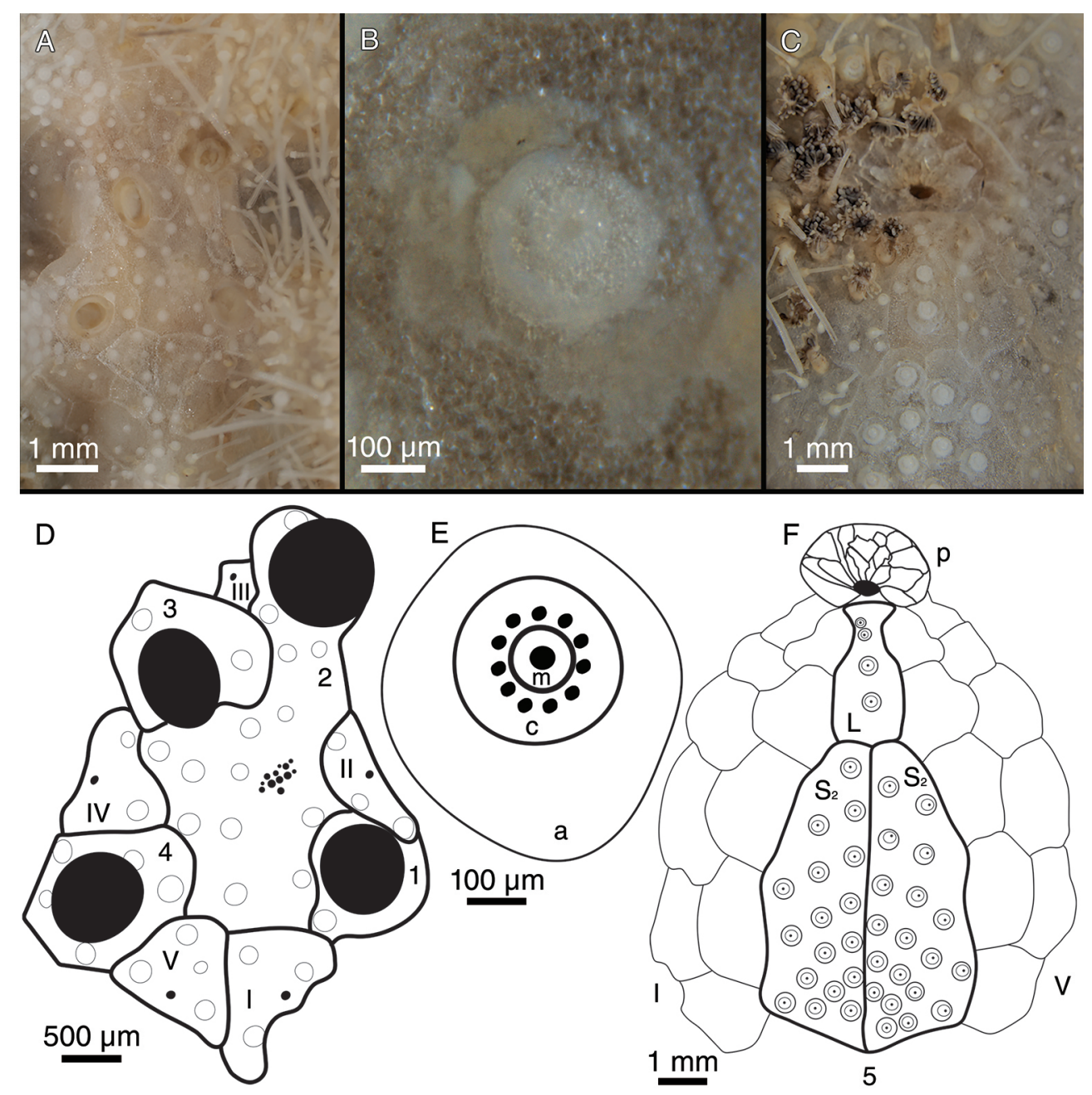

Fig. 4. Morphological details and drawings of Corparva lyrida gen. et sp. nov. A. Apical system. B. Primary tubercle. C. Peristome. D. Hemilytic (semi-ethmolytic) apical system plating drawing. E. Primary tubercle diagram. F. Peristome and plastron plating drawing. References: D. $1-4$ genital plates ( 2 also madreporite), and $I-V$ ocular plates; E. $a$ areole, $c$ crenulated platform, and $m$ perforated mamelon; and F. $p$ peristome, $L$ labrum, $S_{2}$ sternal plates, $I$ and $V$ ambulacra, and 5 posterior interambulacrum.

$\mathrm{V}$ and fourth plate in ambulacrum I (Fig. 2B, Fig. 3B), mamelon well-developed with central perforation and slightly crenulated base, areole well-developed (Fig. 4B, Fig. 4E). Secondary tubercles smaller, with same general shape as primary ones, with mamelon usually reduced. Spines scattered on oral side of ambulacra $\mathrm{I}$ and V, but uniformly distributed in sternal plates, ambital region, and apical side (Fig. 2A, Fig. 2B). Primary spines shorter, straight, with pointed tip, and shaft with longitudinal and ornamented striations (Fig. 5D). Longest primary spines found on plastron. They are large, curved and spatulate towards distal end, with well-developed acetabulum and base, poorly developed milled ring, and shaft with longitudinal smooth striations (Fig. 5A, Fig. 5B, Fig. 5C). Spine cylinder with helicoidal pore arrangement (Fig. 5E). Globiferous, tridentate, and triphyllous pedicellariae (Fig. 5H, 


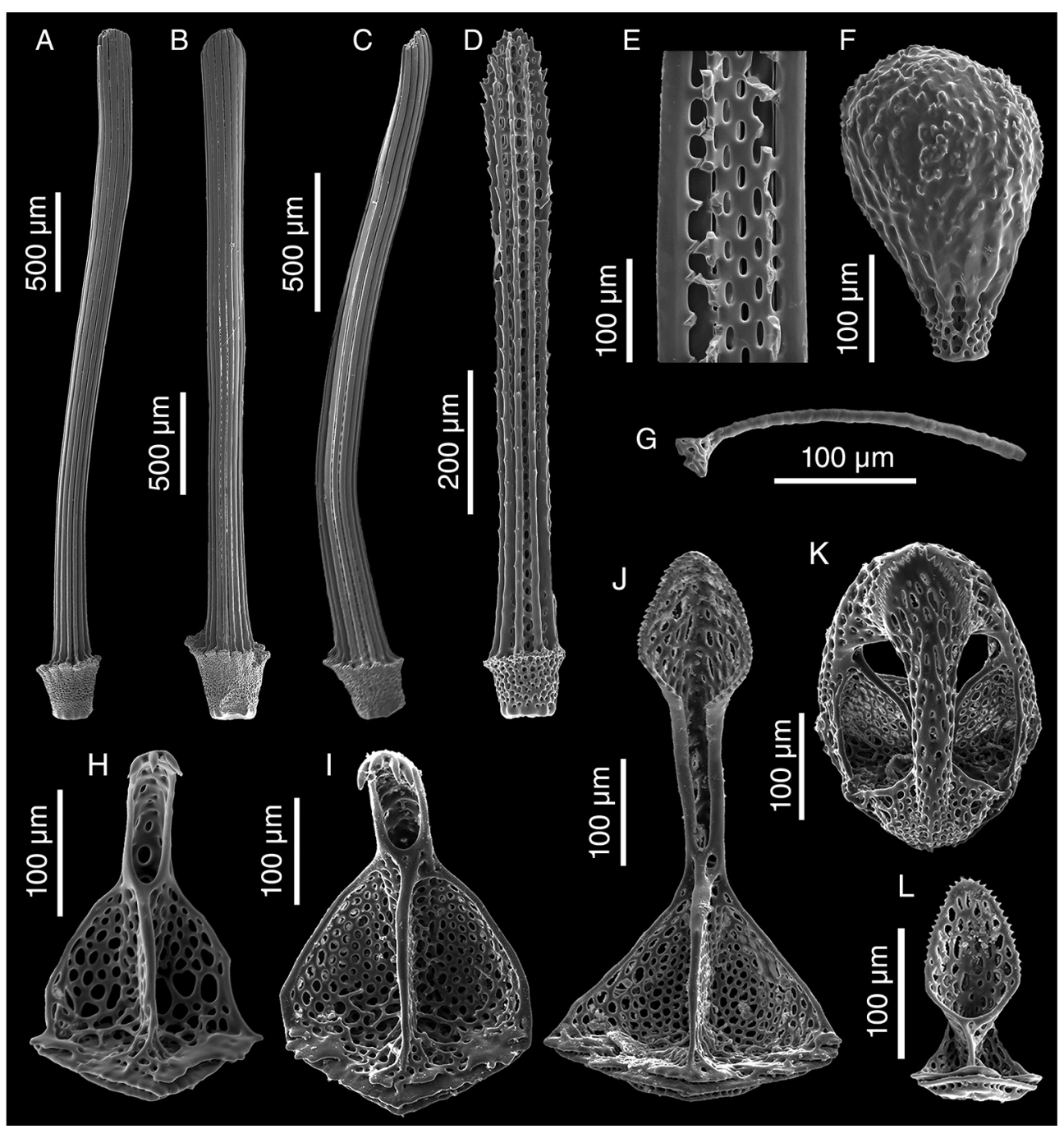

Fig. 5. SEM images of appendages of Corparva lyrida gen. et sp. nov. A-C. Primary spines from the plastron. D. Ambulacrum spine from the oral side. E. View of the inner cylinder of a primary spine. F. Spheridium. G. Skeletal rod from an oral penicillate podium. H-I. Valve of globiferous pedicellaria with three and four terminal teeth, respectively. J. Valve of a tridentate pedicellaria. K. Tridentate pedicellaria. L. Valve of a triphyllous pedicellaria.

Fig. 5I, Fig. 5J, Fig. 5K, Fig. 5L). Globiferous pedicellariae more frequently found on apical side, head and stalk embedded in a yellowish tissue, three-valved, valves whit large and wide base, blade forms a curved semi-tube terminating in 3-6 sharp and tiny hooks (Fig. 5H, Fig. 5I). Tridentate pedicellariae on apical and oral side, three-valved, shovel-shaped valves with widen and finely serrated distal part separated from triangular base by elongated, narrow, and straight tubular part (Fig. 5J, Fig. 5K). Triphyllous pedicellariae smallest, with minute base, and large and wide blade with finely serrated edge (Fig. 5L). Sphaeridiae swollen in shape, irregularly rugose (Fig. 5F), on short stalks, numerous along posterior ambulacral areas on oral side. Test colour brown-brownish with whitish spines in ethanol; denuded test white.

Etymology: lyrida refers to the April Lyrids, the meteor shower that occurs each year 
in the constellation Lyra. The specific name is a noun in apposition (feminine).

Examined material: Holotype MACN-In 43280 (one half denuded specimen in ethanol $70 \%$, and external appendages mounted on three SEM stubs) (Table 1).

Type locality: Mar del Plata Canyon (3806'34" S \& 5342'50” W), Argentine continental slope (Fig. 1B).

Depth: $2950 \mathrm{~m}$.

Distribution: Only know from the type locality (Fig. 1B).

Zoobank ID: urn:lsid:zoobank. org:act:9B 936F 7D-860D-4138-A991673821C3AF48

Remarks: C. lyrida sp. nov. is based on a single complete specimen (holotype MACN-In 43280). Its test is fragile and small (18.2 mm long, $14.8 \mathrm{~mm}$ wide, and $6.0 \mathrm{~mm}$ high), despite this we consider that the specimen studied is an adult, due to the presence of open gonopores. Of course, this supposition is not conclusive but it is in accordance with the characteristic small form of adult specimens among the family Palaeotropidae (Lovén 1871; Koehler, 1914; Mortensen, 1950; Allison, Duncan \& Mintz, 1967; Baker \& Rowe, 1990; Mironov, 2006). Mortensen (1950) report the presence of mature gonads containing a few ripe eggs in a specimen of Palaeotropus josephinae of $14 \mathrm{~mm}$ length.

In some spatangoids, fascioles may be present during all stage of development, in others they are present in juveniles and then maybe secondarily lost in adults, and in some taxa there is no evidence that fascioles were developed during ontogeny (Smith \& Stockley, 2005; Stockley et al., 2005). Due to the holotype of $C$. lyrida sp. nov. does not present any trace of fascioles, and it is the only specimen that we have, we assumed that fascioles are absent at least in adults. Additional specimens in different stages of development are needed to test if fascioles develop during ontogeny or it is completely lost in C. lyrida sp. nov.

Corparva lyrida sp. nov. shows various secondary morphological simplifications that suggest an epibenthic lifestyle. As is observed in many others deep-sea spatangoids (Larrain, 1985; Stockley et al. 2005; Saitoh \& Kanazawa, 2012), C. lyrida sp. nov. has features related with the building and maintenance of sanitary funnels poorly developed (absence of fascioles and distinctive tufts of spines on the aboral side or at the posterior end of the test, and the inframarginal position of the anus). Besides, others ecological traits present in deep-sea taxa and $C$. lyrida are the test thinner than shallow waters spatangoids, and the poorly developed (or completely lost in some groups) of petals and specialized tube feet, due to in the deep-sea the respiratory demanding is less than in shallow waters (Stockley et al., 2005).

Family Schizasteridae Lambert, 1905

Genus Tripylus Philippi, 1845

Tripylus excavatus (Philippi, 1845)

(Fig. 6A)

Examined material: MACN-In 43270 (Table 1).

Distribution: Tripylus excavatus occurs northward in the SWAO at $39^{\circ} \mathrm{S}$ (this study), and southward occurs along the Strait of Magellan, Tierra del Fuego, Isla de los Estados, and Cape Horn (Fig. 1C) (Fabri-Ruiz et al., 2017). Also recorded at South Georgia Islands (Saucède et al., 2020).

Depth: From the littoral to $110 \mathrm{~m}$ depth (Saucède et al., 2020).

Remarks: Here we report the northernmost record for $T$. excavatus at $39^{\circ} 05^{\prime} 49^{\prime \prime} \mathrm{S}$ $\& 58^{\circ} 02^{\prime} 09^{\prime \prime} \mathrm{W}$ at $74 \mathrm{~m}$ depth (Table 1, Fig. $1 \mathrm{C})$, resulting in a great extension in its range of distribution. Despite its broad wide range, T. excavatus seems to be an unusual species. Among 299 spatangoids collected we found only three specimens, this peculiarity also was highlighted by Bernasconi $(1953,1966)$. In this line, is to be expected that the disjunct distribution shown in figure $1 \mathrm{C}$ became continuous as the sampling increasing in both effort and quality for this area. 


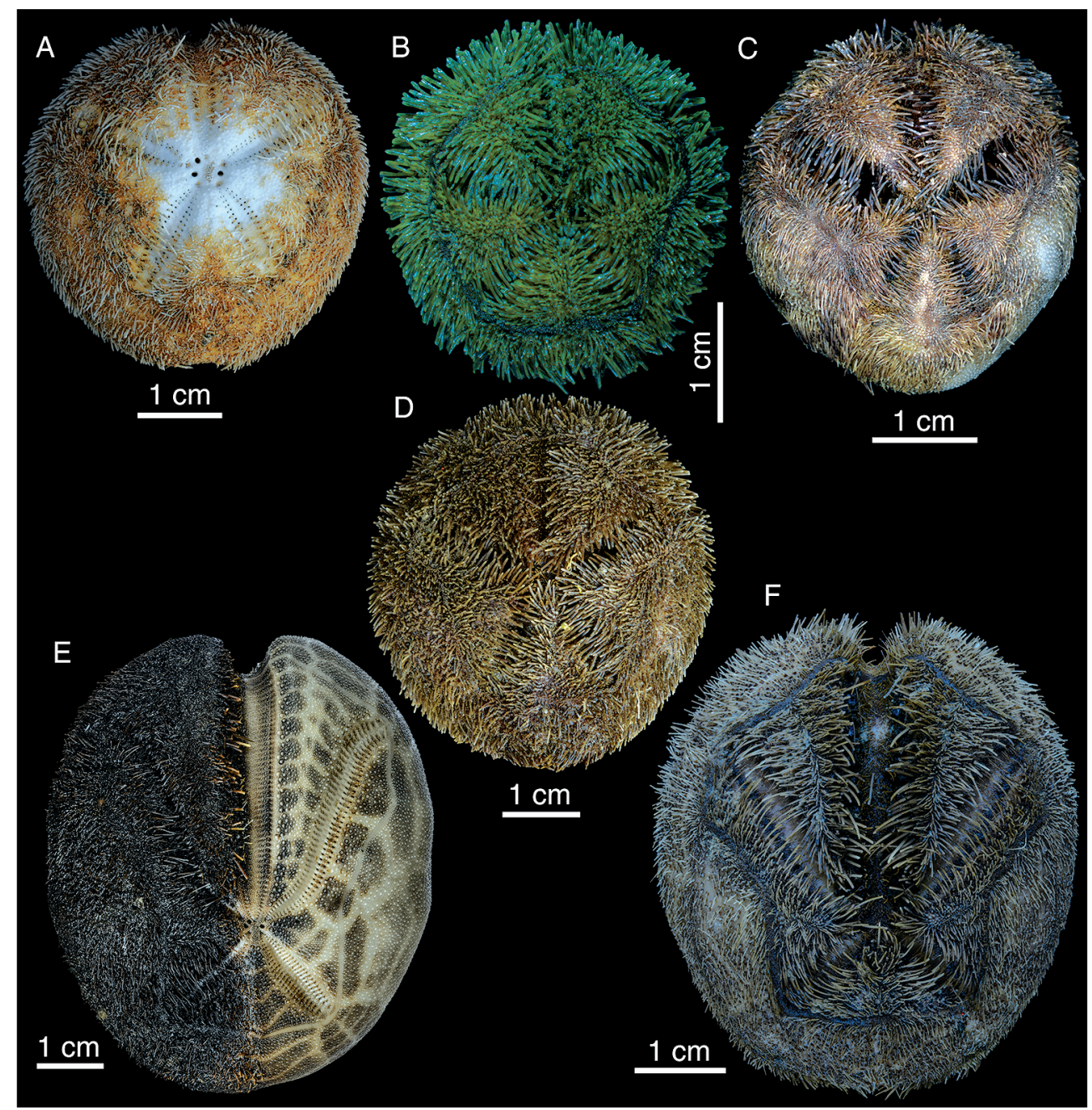

Fig. 6. Images of specimens discussed in the present study. A. Aboral view of Tripylus excavatus (Philippi, 1845) (MACNIn 43270, specimen partially cleaned). B. Aboral view of Abatus cavernosus (Philippi, 1845) (MACN-In 43314). C. Aboral view of Abatus philippii Lovén, 1871 (MACN-In 43273). D. Aboral view of Abatus agassizii Mortensen, 1910 (MACN-In 43304). E. Aboral view of Brisaster moseleyi (A. Agassiz, 1881) (MACN-In 43309), specimen partially cleaned). F. Aboral view of Tripylaster philippii (Gray, 1851) (MACN-In 43316).

Tripylus reductus (Koehler, 1912)

Examined material: MACN-In 43285, MACN-In 43286, MACN-In 43297, MACNIn 43299 (Table 1).

Distribution: T. reductus is restricted to the southern region of the SWAO (Tierra del Fuego, Isla de los Estados) (Fig. 1D), and the northern part of the Antarctic Peninsula, also
South Shetland Islands, and South Orkney Islands (Saucède et al., 2020).

Depth: From 50 to $761 \mathrm{~m}$ depth (Saucède et al., 2020).

\section{Tripylus sp.}

Examined material: MACN-In 43302 (Table 1). 
Distribution: Isla de los Estados.

Depth: $146 \mathrm{~m}$.

Remarks: Test fragment identified at the generic level due to the lack of diagnostic characters.

Genus Abatus Troschel, 1851

Abatus cavernosus (Philippi, 1845)

(Fig. 6B)

Examined material: MACN-In 43314 (Table 1).

Distribution: Wide distribution along the SWAO from $35^{\circ} \mathrm{S}$ to $55^{\circ} \mathrm{S}$, including the Straits of Magellan, and Malvinas Islands (Fig. 1E) (Brogger et al., 2013). Also, along the Antarctic Peninsula, South Orkney Islands, South Georgia Islands, South Shetland Islands, and Bouvet Islands (David, Saucède, Chenuil, Steimetz \& De Ridder, 2016; Saucède et al., 2020).

Depth: From 10 to $1000 \mathrm{~m}$ depth (Saucède et al., 2020). Abatus cavernosus is commonly found in shallow waters southward of $44^{\circ} \mathrm{S}$, while northward off Buenos Aires it occurs from 100 to $1000 \mathrm{~m}$ depth (Brogger et al., 2013; Saucède et al., 2020).

\section{Abatus philippii Lovén, 1871} (Fig. 6C)

Examined material: MACN-In 43269, MACN-In 43272, MACN-In 43273, MACNIn 43276, MACN-In 43277, MACN-In 43287, MACN-In 43288, MACN-In 43290, MACN-In 43291, MACN-In 43292, MACN-In 43294, MACN-In 43295, MACN-In 43298, MACNIn 43301, MACN-In 43305, MACN-In 43306, MACN-In 43308, MACN-In 43323 (Table 1).

Distribution: Widely distributed along the $\mathrm{SWAO}$ from $35^{\circ} \mathrm{S}$ to $55^{\circ} \mathrm{S}$, including the Strait of Magellan, Isla de los Estados, Malvinas Islands (Bernasconi, 1964; Bernasconi,1966; Fabri-Ruiz et al., 2017), and the MPA-N/BB (this study). In the southeastern Pacific Ocean at $52^{\circ} \mathrm{S}$ latitude. In the Southern Ocean recorded at South Georgia Islands, South Shetland
Islands, South Orkney Island, Sabrina Coast, and Ross Sea (Saucède et al., 2020).

Depth: From 25 to $800 \mathrm{~m}$ depth (Saucède et al., 2020).

Remarks: Here we report the first record for A. philippi at the MPA-N/BB (Table 1). Due to the occurrence of the species in surrounding areas, its presence in the AMP-N/BB was expected (Fig. 1F).

\section{Abatus agassizii Mortensen, 1910}

(Fig. 6D)

Examined material: MACN-In 43293, MACN-In 43296, MACN-In 43300, MACNIn 43303, MACN-In 43304, MACN-In 43307 (Table 1).

Distribution: A. agassizii occurs in the southern region of the SWAO, including Tierra del Fuego, Isla de los Estados, Malvinas Islands (Bernasconi, 1964; Saucéde et al., 2020), and the AMP-N/BB (this study) (Fig. 1G). Also recorded in the Southern Ocean at South Georgia Islands, South Shetland Island, the northern end of the Antarctic Peninsula, and in the eastern Weddell Sea (Saucède et al., 2020).

Depth: From the littoral to $600 \mathrm{~m}$ depth (Saucède et al., 2020).

Remarks: Here we report the first record for $A$. agassizii at the MPA-N/BB (Table). The range of distribution known for $A$. agassizii seems to have a north limit at Malvinas Islands. These new records for the AMP-N/BB are in accord with the distribution area known for the species (Fig. 1G).

\section{Abatus sp.}

Examined material: MACN-In 43289, MACN-In 43330 (Table 1).

Distribution: MPA-N/BB.

Depth: MACN-In 43289 at $135 \mathrm{~m}$ depth, and MACN-In 43330 at $100 \mathrm{~m}$ depth

Remarks: Two test fragments identified at the generic level due to the lack of diagnostic characters. 
Genus Brisaster Gray, 1855

Brisaster moseleyi (A. Agassiz, 1881)

(Fig. 6E)

Examined material: MACN-In 43274, MACN-In 43275, MACN-In 43278, MACNIn 43279, MACN-In 43281, MACN-In 43282, MACN-In 43283, MACN-In 43284, MACN-In 43309 (Table 1).

Distribution: $B$. moseleyi is recorded on both side of South America, in the southeastern Pacific Ocean off Chile from $45^{\circ} \mathrm{S}$ to $54^{\circ} \mathrm{S}$, the Straits of Magellan, and in the SWAO recorded at Malvinas Islands (Saucède et al., 2020). We report the first record of $B$. moseley $i$ at both the northwest slope surrounding the MPA-N/BB, and the Mar del Plata Canyon (Fig. 1H). In the Southern Ocean recorded at South Orkney Islands (Saucède et al., 2020).

Depth: From 400 m (Saucède et al., 2020) to $2212 \mathrm{~m}$ depth (this study) (Table 1).

Remarks: According to Saucède et al. (2020) the known geographic and bathymetric limit for B. moseleyi was the Malvinas (Falkland) Islands in the SWAO and $1400 \mathrm{~m}$ depth, respectively. Here we report the northernmost, as well as the deepest distribution for B. moseleyi so far known. The former is the Mar del Plata Canyon on the Argentine continental slope (38॰01'23" S \& 53 51'00" W), and the second $2212 \mathrm{~m}$ depth (MACN-In 43281) (Table 1). In addition, we report its occurrence at the northwest slope of the MPA-N/ $\mathrm{BB}$ at $642 \mathrm{~m}$ depth (MACN-In 43309) (Fig. $1 \mathrm{H})$. While $B$. moseleyi is a typical deep-sea species, it should be mentioned that also was found in the shallow waters from the Strait of Magellan by Larraín et al. (1999). Thus, the records here presented confirm for the first time the presence of $B$. moseleyi in deep waters off Argentina, an extraordinary extension to its geographic and bathymetric range.

Hood and Mooi (1998) pointed out that examined specimens labelled as $B$. moseleyi from Chile (southeastern Pacific Ocean) were distinct from other B. moseleyi from the Malvinas Islands and Patagonia (SWAO) and considered them as two distinct taxa termed " $B$. moseleyi (north)" and "B. moseleyi (south)" respectively. Also, their phylogenetic analysis based in morphological characters revealed that $B$. moseleyi (north) is more closely related to those species of Brisaster from the west coast of the Americas, while B. moseleyi (south) is a sister taxon of $B$. antarcticus (Döderlein, 1906). Brisaster moseleyi (south) and B. antarcticus differ from $B$. moseleyi (north) by possessing narrow petals IV and V, and long and narrow plastron (Hood \& Mooi, 1998), these features were also present in the specimens treated in this study (Fig. 6E). Besides, following the identification key provided by Saucède et al. (2020) the specimens collected match well with their $B$. moseleyi entity, differing from $B$. antarcticus by having the apical system slightly displaced posteriorly, and the posterior petals short, slightly more than $1 / 3$ the length of the anterior paired petals (Fig. 6E). Due to the uncertainty in taxonomic distinctiveness and to avoid possible futures nomenclature troubles, the specimens treated in this study are provisionally assigned to $B$. moseleyi. Genetic studies could help reveal the specific validation of the north/south groups and possible synonyms, enriched through the inclusion of samples from the northernmost population of B. moseleyi found at the Mar del Plata Canyon on the Argentine continental slope SWAO, and to reconstruct phylogenetic relationships among Brisaster species.

Genus Tripylaster Mortensen, 1907

Tripylaster philippii (Gray, 1851)

(Fig. 6F)

Examined material: MACN-In 43271, MACN-In 43310, MACN-In 43311, MACNIn 43312, MACN-In 43313, MACN-In 43315, MACN-In 43316, MACN-In 43317, MACN-In 43318, MACN-In 43319, MACN-In 43320, MACN-In 43321, MACN-In 43322, MACNIn 43324, MACN-In 43325, MACN-In 43326, MACN-In 43327, MACN-In 43328, MACN-In 43329 (Table 1).

Distribution: T. philippii occurs at the SWAO from $35^{\circ} \mathrm{S}$ up to the southeastern 
Pacific Ocean at $41^{\circ} \mathrm{S}$, including the Strait of Magellan, Tierra del Fuego, Isla de los Estados, and Malvinas Islands (Fig. 1I) (Bernasconi, 1964; Fabri-Ruiz et al., 2017). Also recorded at the South Georgia Islands, and close to Prince Edward Island (Saucède et al., 2020).

Depth: From the littoral to $600 \mathrm{~m}$ depth (Saucède et al., 2020).

\section{DISCUSSION}

The family Palaeotropidae comprises six genera including the new genus here described. Comparing structural features and shape of the test, development of petals, the shape of peristome, and aboral tuberculation, Corparva gen. nov. conform within the Palaetropidae. Besides, Corparva gen. nov. can be differentiated from the rest Palaeotropidae by its apical system semi-ethmolytic and its labral plate reaching to rear part of second adjacent ambulacral plate. C. lyrida sp. nov. is known only from abyssal depths at the Mar del Plata Canyon on the Argentine continental slope, and it is sympatric with others spatangoids herein treated. This new genus and species represent the first report on the family Palaeotropidae from Argentina.

Many authors have pointed out the high incidence of benthic marine invertebrates with non-pelagic development and high rates of parental care in the SWAO and the Southern Ocean (Poulin \& Féral, 1996, 1998; Pearse, Mooi, Lockhart \& Brandt, 2009), and echinoids are not an exception. Although species of the genera Brisaster, and Tripylaster are broadcast spawners with indirect development through planktotrophic larvae, members of the genera Abatus, Tripylus, Parapneustes and Delopatagus are brooders and present a lecithotrophic development (Mortensen, 1951; Pearse \& Cameron, 1991; Poulin \& Féral, 1996; Gil, Zaixso \& Tolosano, 2009). Also, the distinction between sexes in echinoids is frequently expressed by sexual dimorphism, such as the form of genital papillae and the size of genital pores (among others). Mostly in brooding spatangoids, the females present extreme secondary sexual features associated with this reproduction strategy, such as the modification of the aboral region of the test into marsupial brood pouches that give protection for the development of embryos and juveniles (David \& Mooi, 1990; Gil, Zaixso \& Tolosano, 2020). The depressed ambulacra as an aboral brooding system were widely described for different spatangoids taxa (Mortensen, 1951; Philip \& Foster, 1971; Schinner \& McClintock, 1993). Corparva lyrida sp. nov presents large gonopores and the paired ambulacra are deeply depressed forming rounded pouches. A lecithotrophic developmental mode for the species can be suspected, due to large gonopores is associated with the production of large yolky eggs (Pearse \& Cameron, 1991). The apical system of $C$. lyrida sp. nov is sunken with respect to the extreme of the interambulacral areas and the ambulacral pouches are slightly deeper than the apical system as well, forming a wide sunken cruciform area (Fig. 3A). This area is cover by long primary spines that emerge leaned over towards the center of the animal body from the upper external edges of the ambulacral plates and surrounding interambulacral plates, and by pedicellariae (Fig. 2A), resulting in a protected chamber. Although no embryos, nor juveniles were found into the chamber, the morphological features previously mentioned suggesting that the specimen could be a female with marsupial brood chamber

Although is necessary to increase the sampling effort and use a proper experimental design to conclude on biogeographical issues, from this study some exploratory trends can be observed in the distribution of the spatangoids here studied (Fig. 1). The species composition in the SWAO has sub-Antarctic and Antarctic affinities. This could be explained in part by the presence of water masses formed in these regions of the world and they are carried to the SWAO by the MC, which could be acting as a dispersal vector of propagules and larvae. Recently studies about biogeographical patterns and benthic eco regionalization based on echinoids from the Southern Ocean, highlights the strongly faunal affinities between South 
America and sub-Antarctic islands, possibly due to the connectivity by the flow of the Antarctic Circumpolar Current (Pierrat, Saucède, Brayard \& David, 2013; Fabri-Ruiz, Danis, Navarro, Koubbi, Laffont \& Saucède, 2020). However, is interesting to highlight that $C$. lyrida sp. nov. was found at $2950 \mathrm{~m}$ depth at the Mar del Plata Canyon on the Argentine continental slope, and in this region between 2000 to $3000 \mathrm{~m}$ there is present the North Atlantic Deep Water (Voigt et al., 2013), which is originated at the North Atlantic Ocean, and flush southward along the continental slope of the American continent (Piola \& Matano, 2001)

The present work brings novel and updated data about the diversity and distribution of spatangoid sea urchins from the SWAO, including the description of $C$. lyrida a new genus and species from abyssal waters off Argentina, new records, and occurrence of species previously reported. This reveals that there is still much to know about the diversity and distribution of heart urchins in the SWAO, especially from the deep-sea. Moreover, the knowledge in these aspects will contribute to clarify the matted phylogenetic and evolutionary relations among the Spatangoida taxa.

Ethical statement: authors declare that they all agree with this publication and made significant contributions; that there is no conflict of interest of any kind; and that we followed all pertinent ethical and legal procedures and requirements. All financial sources are fully and clearly stated in the acknowledgements section. A signed document has been filed in the journal archives.

\section{ACKNOWLEDGMENTS}

We are grateful to the different crews of the R/V Puerto Deseado, and the scientific staff involved in each cruise. JNF would like to thank Carlos Conejeros-Vargas for his observations that enriched an early version of this work. The final version greatly benefitted from helpful comments by four anonymous reviewers. We thank Fabián Tricárico for his assistance with the SEM and to Daniel Lauretta for facilitating the camera and lens. We acknowledge the Consejo Nacional de Investigaciones Científicas y Técnicas (CONICET) of Argentina, to which JNF belong as a $\mathrm{PhD}$ fellow, and PEP and MIB as members of the "Carrera del Investigador Científico y Tecnológico". This work is the contribution $\mathrm{N}^{\circ} 44$ to the Área Marina Protegida Namuncurá (MPA-N/BB, Ley 26.875).

\section{RESUMEN}

\section{Erizos corazón de las profundidades: Corparva lyrida gen. et sp. nov. (Palaeotropidae) y nuevos registros para el Océano Atlántico sudoccidental}

Introducción: Los erizos de mar del orden Spatangoida son el grupo más diverso de equinoideos recientes. Objetivo: Describir un nuevo género y una nueva especie de Spatangoida de profundidades abisales, y reportar nuevos registros para especies conocidas. Métodos: Los ejemplares fueron recolectados durante varias expediciones a diferentes áreas del Océano Atlántico sudoccidental (OAS), entre las latitudes $37-55^{\circ} \mathrm{S}$ y abarcando profundidades desde 55 a 3000 metros. Presentamos análisis morfológicos y de ultraestructura. Resultados: Corparva lyrida gen. et sp. nov. (Palaeotropidae) fue descripta para el cañón submarino Mar del Plata en el talud continental de Argentina (2950 m de profundidad), el primer registro de esta familia para Argentina. Corparva gen. nov. difiere en tener un sistema apical semi-etmolítico y labrum que llega a la parte posterior de la segunda placa ambulacral adyacente. También informamos la distribución más septentrional y el registro más profundo para Brisaster moseleyi (latitud $38^{\circ} \mathrm{S}, 2212 \mathrm{~m}$ de profundidad), la extensión hacia el norte del rango de distribución de Tripylus excavatus (latitud $39^{\circ} \mathrm{S}, 74 \mathrm{~m}$ de profundidad) y el primer registro de Abatus philippii y Abatus agassizii en el Banco Burdwood/AMP Namuncurá. Conclusiones: El presente trabajo aporta datos novedosos y actualizados sobre la diversidad y distribución de erizos de mar espatangoideos del OAS, incluyendo la descripción de C. lyrida gen. et sp. nov., y nuevos registros para especies conocidas. Esto muestra cuánto queda por conocer sobre la diversidad y distribución de los erizos corazón en el OAS, especialmente de las profundidades marinas.

Palabras clave: Atelostomata; erizos de mar; mar profundo; diversidad; Argentina; AMP-N/BB. 


\section{REFERENCES}

Agassiz, A. (1879). Preliminary Report on the Echini of the Exploring Expedition of H.M.S. "Challenger", Sir C. Wyville Thomson Chief of Civilian Staff. Proceedings of the American Academy of Arts and Sciences, 14, 190-212.

Agassiz, A. (1881). Report on the Echinoidea dredged by HMS “Challenger" 1873-76. Reptort on the Scientific Results of the Voyage of H.M.S. Challenger, 3, 1-321.

Agassiz, A. (1883). Report on the Echini. Reports on the results of dredging, under the supervision of Alexander Agassiz, in the Gulf of Mexico (1877-78), in the Caribbean Sea (1878-79), and along the Atlantic coast of the United States (1880), by the U.S. coast survey steam. In Memoirs of the Museum of Comparative Zology at Harvard Collegelogy, 10(1), 1-227.

Agassiz, L. (1840). Catalogus systematicus Ectyporum Echinodermatum fossilium Musei Neocomiensis, secundum ordinem zoologicum dispositus; adjectis synonymis recentioribus, nec non stratis et locis in quibus reperiuntur. Sequuntur characters diagnostici generum novorum vel minus cognitorum. Petitpierre, Neuchâtel (pp. 20).

Allison, E. C., Durham, J. W., \& Mintz, L. W. (1967). New southeast Pacific echinoids. Occasional Papers of the California Academy of Sciences, 62, 1-23.

Baker, A.N. (1998). The rediscovery of Echinus elevatus Hutton 1872 in New Zealand, and a new name for Acanthotrema Baker \& Rowe 1990 (Echinodermata: Echinoidea). Journal of the Royal Society of New Zealand, 28, 281-286.

Baker, A.N. \& Rowe, F.W.E. (1990). Atelostomatid sea urchins from Australian and New Zealand waters (Echinoidea: Cassiduloida, Holasteroida, Spatangoi$\mathrm{da}$, Neoplampadoida). Invertebrate Taxonomy, 4, 281-316.

Bastida, R., Roux, A., \& Martínez DE. (1992). Benthic communities of the Argentine continental shelf. Oceanologica Acta, 15, 687-698.

Bernasconi, I. (1953). Monografia de los equinodermos argentinos. Anales Del Museo de Historia Natural, $6(2), 1-58$.

Bernasconi, I. (1964). Distribución geográfica de los equinoideos y asteroideos de la extremidad austral de Sudamérica. Boletín Del Instituto de Biología Marina, 7, 43-50.

Bernasconi, I. (1966). Los equinoideos y asteroideos colectados por el buque oceanográfico R/V "Vema", frente a las costas argentinas, uruguayas y sur de Chile. Revista del Museo Argentino de Ciencias Naturales "Bernardino Rivadavia", 9(7), 147-175.
Brogger, M.I., Gil, D.G., Rubilar, T., Martinez, M.I., Díaz De Vivar, M.E., Escolar, M., . . . Tablado, A. (2013). Echinoderms from Argentina: Biodiversity, distribution and current state of knowledge. In J.J. Alvarado \& F.A. Solís-Marin (Eds.), Echinoderm Research and Diversity in Latin America (pp. 359-402). Berlín: Springer Heidelberg.

David, B., \& Mooi, R. (1990). An echinoid that "gives birth": morphology and systematics of a new Antarctic species, Urechinus mortenseni (Echinodermata, Holasteroida). Zoomorphology, 110, 75-89.

David, B., Saucède, T., Chenuil, A., Steimetz, E., \& De Ridder, C. (2016). The taxonomic challenge posed by the Antarctic echinoids Abatus bidens and Abatus cavernosus (Schizasteridae, Echinoidea). Polar Biology, 39(5), 897-912.

De Ridder, C., Jangoux, M., \& De Vos, L. (1987). Frontal ambulacral and peribuccal areas of the spatangoid echinoid Echinocardium cordatum (Echinodermata): a functional entity in feeding mechanism. Marine Biology, 94, 613-624.

Doti, B.L., Roccatagliata, D. \& López Gappa, J. (2014). An inverse latitudinal biodiversity pattern in asellote isopods (Crustacea, Peracarida) from the Southwest Atlantic between $35^{\circ}$ and $56^{\circ} \mathrm{S}$. Marine Biodiversity, 44(1), 115-125.

Döderlein, L.H.P. (1906). Die Echinoiden der deutschen Tiefsee-Expedition. Wissenschaftliche Ergebnisse der Deutschen Tiefsee-Ex-pedition auf dem Dampfer "Valdivia"1898-1899, 5(2), 61-290.

Fabri-Ruiz, S., Danis, B., Navarro, N., Koubbi, P., Laffont, R., \& Saucède, T. (2020). Benthic ecoregionalization based on echinoid fauna of the Southern Ocean supports current proposals of Antarctic Marine Protected Areas under IPCC scenarios of climate change. Global Change Biology, 26(4), 2161-2180.

Fabri-Ruiz, S., Saucède, T., Danis, B., \& David, B. (2017). Southern ocean echinoids Database - An updated version of Antarctic, Sub-Antarctic and cold temperate echinoid database. ZooKeys, 697, 1-20.

Gil, D.G., Zaixso, H.E., \& Tolosano, J.A. (2009). Brooding of the sub-Antarctic heart urchin, Abatus cavernosus (Spatangoida: Schizasteridae), in southern Patagonia. Marine Biology, 156, 1647-1657.

Gil, D.G., Zaixso, H.E., \& Tolosano, J.A. (2020). Sexspecific differences in gonopore and gonadal growth trajectories in the brooding sea urchin, Abatus cavernosus (Spatangoida). Invertebrate Biology, 139(1), $1-8$.

Gray, J.E. (1851). Descriptions of some new genera and species of Spatangidae in the British Museum. The Annals and Magazine of Natural History, 2(7), 130-134. 
Gray, J.E. (1855). Catalogue of the Recent Echinida, or sea eggs, in the collection of the British Museum. Part 1 - Echinida Irregularia (69 pp.). London: Woodfall and Kinder.

Hood, S., \& Mooi, R. (1998). Taxonomy and phylogenetics of extant Brisaster (Echinoidea: Spatangoida). In R. Mooi \& M. Telford (Eds.), Echinoderms: San Francisco (pp. 681-686). Netherlands: Balkema, Rotterdam.

Koehler, R. (1907). Astéries, ophiures et échinides recueillis dans les mers australes par la Scotia 1902-1904. Zoologischer Anzeiger, 32, 140-147.

Koehler, R. (1912). Deuxième Expédition Antarctique Française (1908-1910). Echinodermes (astéries, ophiures et échinides) (pp. 1-270). Paris: Masson et Cie.

Koehler, R. (1914). Échinides du Musée Indien à Calcutta. I. Spatangidés. Echinoderma of the Indian Museum. Part 8, Echinoidea (1). Zoological Survey of India. Calcutta, 1-258.

Kroh, A. (2020). Chapter 1. Phylogeny and classification of echinoids. In: Lawrence, J.M. (ed.): Sea Urchins. Biology and Ecology, $4^{\text {th }}$ Edition (pp. 1-17). Developments in Aquaculture and Fisheries Science,vol. 43). Amsterdam: Elsevier.

Kroh, A. \& Smith, A.B. (2010). The phylogeny and classification of post-Palaeozoic echinoids. Journal of Systematic Palaeontology, 8(2), 147-212.

Kroh, A. \& Mooi, R. (2020). World Echinoidea Database. Accessed at http://www.marinespecies.org/echinoidea on 2020-09-25.

Lambert, J. (1896). Note sur quelques échinides crétacés de Madagascar. Bulletin de la Société Géologique de France, Series 3, 24, 313-332.

Lambert, J. (1905). Echinides du sud de la tunisie (environs de tatahouine). Bulletin de La Société Géologique de France, Series 4, 6, 695-723.

Larrain, A.P. (1985). Brachysternaster, new genus, and Brachysternaster chesheri, new species of Antarctic echinoid (Spatangoida, Schizasteridae). Polar Biology, 4(3), 121-124.

Larraín, A., Mutschke, E., Riveros, A., \& Solar, E. (1999). Preliminary report on Echinoidea and Asteroidea (Echinodermata) of the joint Chilean-German-Italian Magellan "Victor Hensen" campaign, 17 October - 25 November 1994. Scientia Marina, 63(1), 433-438.

Leske, N.G. (1778). Jacobi Theodori Klein naturalis dispositio echinodermatum . . ., edita et descriptionibus novisque inventis et synonomis auctorem aucta. Addimenta ad I. T. Klein naturalem dispositionem Echinodermatum. G. E. Beer, Leipzig, 278 pp.
Lohrer, A.M., Thrush, S.F., Hunt, L.,Hancock, N., \& Lundquist, C. (2005). Rapid reworking of subtidal sediments by burrowing spatangoid urchins. Journal of Experimental Marine Biology and Ecology, 321, 155-169.

López Gappa, J., Alonso, G.M. \& Landoni, N.A. (2006). Biodiversity of benthic Amphipoda (Crustacea: Peracarida) in the Southwest Atlantic between $35^{\circ} \mathrm{S}$ and 56 ${ }^{\circ}$ S. Zootaxa, 1342, 3-66.

Lovén, S. (1871). Om Echinoideernas byggnad. Öfversigt af Kongl. Vetenskaps-Akademiens Förhandlingar, 28(8): 1065-1111.

Lovén, S. (1874). Études sur les échinoïdées. Kongelige Svenska Vetenskaps-Akademiens Handlingar, 11, $1-91$.

Markov, A.V., \& Solovjev, A.N. (2001). [Echinoids of the family Paleopneustidae (Echinoidea, Spatangoida), morphology, taxonomy, phylogeny]. [in russian]. Trudy Paleontologicheskogo Instituta, Rossikaia Akademia Nauk, 280, 1-108.

Matano, R.P., Palma, E.D., \& Piola, A.R. (2010). The influence of the Brazil and Malvinas Currents on the Southwestern Atlantic Shelf circulation. Ocean Science, 6(4), 983-995.

Mironov, A.N. (1978). [The most deep-sea species of sea urchins (Echinoidea, Pourtalesiidae)]. Zoologicheskii Zhurnal, 57(5): 721-726.

Mironov, A.N. (2006). Echinoids from seamounts of the north-eastern Atlantic; onshore/offshore gradients in species distribution. In A. N. Mironov, A. V. Gebruk, \& A. J. Southward (Eds.), Biogeography of the North Atlantic Seamounts KMK Scientific Press, Russian Academy of Sciences (pp. 96-133). Moscow.

Mortensen, T. (1907). Echinoidea (part. 2). The Danish Ingolf-Expedition. 4(2): 1-200. Copenhague: Bianco Luno impr.

Mortensen, T. (1910). The Echinoidea of the Swedish South Polar Expedition. Schwedischen Südpolar Exp. 1901-1903. Wissenschaftliche Ergebnisse Der Schwedischen Südpolar Expedition, 6(4), 1-114.

Mortensen, T. (1950). A monograph of the Echinoidea. V. 1 Spatangoida. I. Copenhagen: Reitzel, C.A.

Mortensen, T. (1951). A monograph of the Echinoidea. V. 2 Spatangoida II. Copenhagen: Reitzel, C.A.

Néraudeau, D., David, B., \& Madon, C. (1998). Tuberculation in spatangoid fascioles: Delineating plausible homologies. Lethaia, 31(4), 323-333

Pierrat, B., Saucède, T., Brayard, A., \& David, B. (2013). Comparative biogeography of echinoids, bivalves and gastropods from the Southern Ocean. Journal of Biogeography, 40(7), 1374-1385. 
Piola, A.R. \& Matano, R.P. (2001). Brazil and Falklands (Malvinas) currents. In J.H. Steele, S.A. Thorpe \& K.K. Turekian (Eds.), Encyclopedia of Oceans Science: Ocean Currents (pp. 340-349). London: Academic Press.

Pearse, J.S., \& Cameron, R.A. (1991). Echinodermata: Echinoidea. In Giese, Pearse \& Pearse (Eds.), Reproduction of marine invertebrates, Echinoderms and lophophorates (pp. 513-662). California: Boxwood Press.

Pearse, J.S., Mooi, R., Lockhart, S.J., \& Brandt, A. (2009). Brooding and Species Diversity in the Southern Ocean: Selection for Brooders or Speciation within Brooding Clades?. Smithsonian at the Poles : Contributions to International Polar Year Science, 1971, 181-196.

Philip, G.M., \& Foster, R.J. (1971). Marsupiate tertiary echinoids from south-eastern Australia and their zoogeographic significance. Palaeontology, 14(4), 666-695.

Philippi, A. (1845). Beschreibung einiger neuen Echinodermen nebst kritischen Bemerkungen über einige weniger bekannte Arten. Archiv für Naturgeschichte, $11,344-359$

Poulin, E., \& Féral, J.P. (1996). Why are there so many species of brooding antarctic echinoids?. Evolution, $50(2), 820$

Poulin, E., \& Féral, J.P. (1998). Consequences of brood protection in the diversity of antarctic echinoids. Oceanis, 24(4), 159-188.

Saitoh, M., \& Kanazawa, K. (2012). Adaptative morphology for living in shallow water environments in spatangoid echinoids. Zoosymposia, 7(1), 255-265.

Saucède, T., Eléaume, M., Jossart, Q., Moreau, C., Downey, R., Bax, N., Sands, C., Mercado, B., Gallut, C., \& Vignes-Lebbe, R. (2020). Synthesis Taxonomy 2.0: computer-aided identification tools to assist Antarctic biologists in the fiel and in the laboratory. Antarctic Science, 1-13.
Schinner, G.O., \& McClintock, J.B. (1993). Structural characteristics of marsupial brood pouches of the antarctic sea urchins Abatus nimrodi and Abatus shackletoni (Echinoidea: Spatangoida). Journal of Morphology, 216(1), 79-93.

Smith, A.B., \& Gale, A.S. (2009). The pre-Messinian deepsea Neogene echinoid fauna of the Mediterranean: Surface productivity controls and biogeographical relationships. Palaeogeography, Palaeoclimatology, Palaeoecology, 281(1-2), 115-125.

Smith, A.B., \& Kroh, A. (Eds.). (2011). The Echinoid Directory. World Wide Web electronic publication. Retrieved from http://www.nhm.ac.uk/researchcuration/projects/echinoid-directory [accessed April, 2020].

Smith, A.B., \& Stockley, B. (2005). Fasciole pathways in spatangoid echinoids: A new source of phylogenetically informative characters. Zoological Journal of the Linnean Society, 144(1), 15-35.

Stockley, B., Smith, A.B., Littlewood, T., Lessios, H.A., \& Mackenzie-Dodds, J.A. (2005), Phylogenetic relationships of spatangoid sea urchins (Echinoidea): taxon sampling density and congruence between morphological and molecular estimates. Zoologica Scripta, 34, 447-468.

Troschel, F.H. (1851). Ueber die Gattung Tripylus. Archiv für Naturgeschichte, 17, 67-74.

Villier, L., Néraudeau, D., Clavel, B., Neumann, C., \& David, B. (2004). Phylogeny of early cretaceous spatangoids (Echinodermata: Echinoidea) and taxonomic implications. Palaeontology, 47(2), 265-292.

Voigt, I., Henrich, R., Preu, B. M., Piola, A. R., Hanebuth, T. J. J., Schwenk, T., \& Chiessi, C. M. (2013). A submarine canyon as a climate archive - Interaction of the antarctic intermediate water with the mar del plata canyon (southwest atlantic). Marine Geology, 341, 46-57. 